For citation: Steblyanskaya A., Wang Zh., Ryabova E. V., Razmanova S. V. (2019). Russian Gas Companies' Financial Strategy Considering Sustainable Growth. Ekonomika Regiona [Economy of Region], 15(1), 231-241

doi 10.17059/2019-1-18

UDC 338.1

\author{
A. Steblyanskaya a) Zh. Wang $^{\text {a) }}$, E. V. Ryabova ${ }^{\text {b) }}$, S. V. Razmanova ${ }^{\text {c) }}$ \\ a) China University of Petroleum (Beijing, China; e-mail: alinamv@bk.ru) \\ b) National Research University Higher School of Economics, campus in Nizhny Novgorod \\ (Nizhny Novgorod, Russian Federation) \\ c) Branch Office of LLC Gazprom VNIIGAZ in Ukhta (Ukhta, Russian Federation)
}

\title{
RUSSIAN GAS COMPANIES' FINANCIAL STRATEGY CONSIDERING SUSTAINABLE GROWTH
}

Over the past ten years, an ambiguous situation concerning Russian gas companies has been observed. On the one hand, companies' reports represent conservative policies and sustainable growth in the coming years. On the other hand, companies' financial performance suggests another situation because of the insufficient level of financial indices that reflect the inconsistency of existing sustainable growth approaches. This situation indicates the relevance of the research concerning Russian gas companies' financial sustainable growth in the conditions of the global economy, "economic sanctions" and investment policy implementation. The primary purpose of the research is to analyse Russian gas companies' financial growth strategy employing Geniberg $Z$ - matrix as well as enhanced financial sustainability indicators system indices by identifying which indicators have a greater influence on sustainable growth rate. We found that return on fixed assets ratio, net profit growth ratio, debt equity ratio influence on Russian gas companies' sustainable growth rate and recommended for the system of financial sustainability indicators (FSIS) usage. We associate the concept of Russian gas companies' financial sustainable growth with environmental protection, energy savings, and social factors. Thus, we added to the financial model non-financial factors. As a result of the analysis, we have obtained the dependence of Sustainable Growth Rate to Environmental Ratings as well as Return on social responsibility costs. We recommend paying more attention to the energy, social, environmental, and economic determinants that could contribute to sustainable growth. We also found that Russian gas market companies could improve Financial Strategies according to sustainable growth point of view. We suggest ways to enhance the financial strategy of Russian gas companies.

Keywords: Russian Gas Industry, Russian Gas Companies, Financial Strategy, Financial evaluation, Sustainability, System of Financial Sustainability Indicators (FSIS), Sustainable Growth Rate (SGR), Sustainable Growth Factors, Company's Growth, Geniberg Z-matrix

\section{Introduction}

The Gibrat law in many studies was not confirmed [1, 2], factors affecting the sustainable growth of the company must be sought. The central aspect of the problem is that growth is a qualitative characteristic, but it must be measured somehow. We propose to define financial and non-financial parameters, which have a more significant effect on sustainable growth, with a strong accent on financially sustainable index system.

The rapid investment growth in Russia leads to rapid company's growth, so the critical task for Russia's gas companies is the analysis of the companies' sustainable growth. Different terms have been used by different authors to define the company's growth stages, but the way each company

${ }^{1}$ (c) Steblyanskaya A., Wang Zh., Ryabova E. V., Razmanova S. V. Text. 2019. passes through remains more or less the same ensuring planning and securing the future growth should match company's financial capabilities $[3,4]$. However, in proposed models, sustainable growth is evaluated only as financial performance. In our research, we suppose that sustainable growth depends on non-financial criteria as well. The objective of the study is to analyse Russian gas companies' growth for ten years and try to assess the impact of the criteria of sustainable growth. Research innovation (see Figure1) consists in the enhancement of Russian Gas companies' finance management methodological tools (FSIS) according to the Sustainable Growth reference points.

For this purpose, we modified Sustainable Growth Ratio (further-SGR). According to Financial Sustainability Indicators System (FSIS) we input financial and non-financial indices to improve the company's financial strategy. 


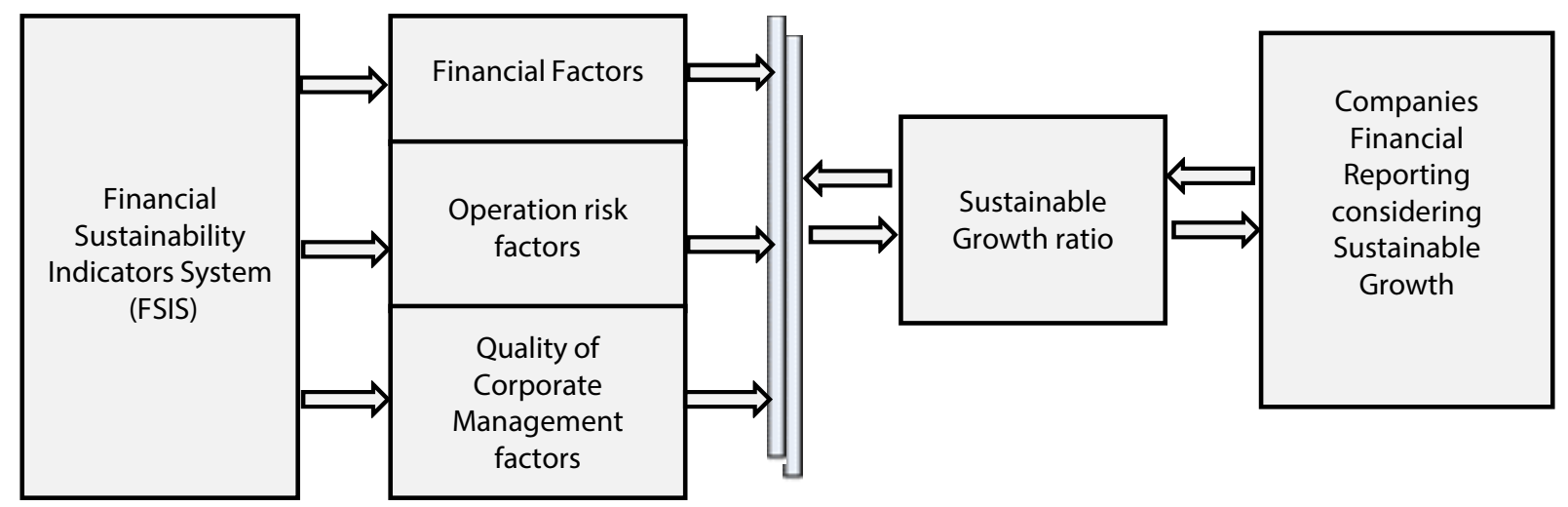

Fig. 1. Research Innovation Scheme
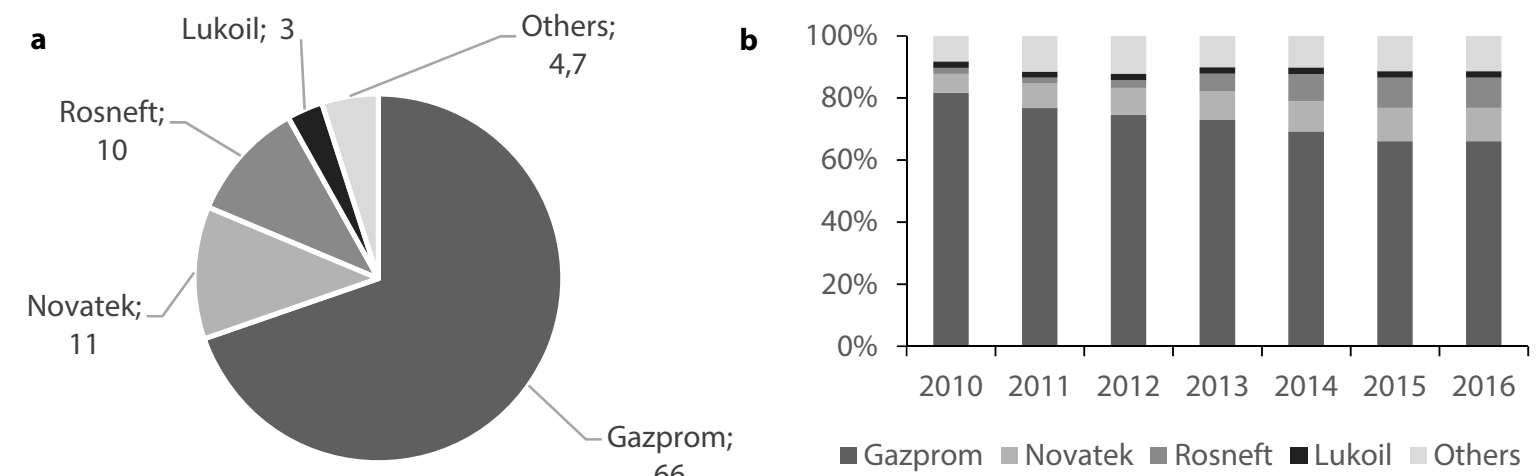

Fig. 2. (a). The share of the Russian gas market companies in the total Russian Gas market, 2016*, \%, (b) Gas Production, bln $m^{3}$

We consider Russian gas market companies' financial data. We analyse ten years period between the years 2005 and 2016. The data source are the annual reports of the four biggest Russian gas companies (Gazprom, Novatek) and oil companies that are also operating in the Russian gas market (Rosneft, Lukoil), which market share the total Russia Gas market in 2016 is $88,6 \%^{1}$ (see Figure 2).

The future of the Russian gas industry is generally determined by implementable projects of the four Russian gas companies (Fig. 2).

The leader in gas production among Russian companies is Gazprom. In 2016, Gazprom extracted 419.1 billion $\mathrm{m}^{3}$ of gas, its share in the global and Russian gas production is amounting to 11 and 66 percent respectively. ${ }^{2}$ The second largest Russian gas company is Novatek, which extracted 67.8 billion $\mathrm{m}^{3}$ of gas in 2016 that constitutes $10.5 \%$ of the Russian production. ${ }^{3}$ Rosneft and Lukoil take the third and fourth places by market share accordingly. During

\footnotetext{
${ }^{1}$ ESRF. (2017). Energy Strategy of the Russian Federation till 2035https://policy.asiapacificenergy.org/sites/default/files/ Energy\%20Strategy\%20of\%20the\%20Russian\%20Federa tion\%20until\%202035.pdf (Date of access: 10.02.2018).

2 Gazprom. (2017). Gazprom Annual Statement, Retrieved from http://www.gazprom.com/ (Date of access: 15.02.2018).

${ }^{3}$ Novatek. (2016). Annual report, 2016, 2016 (May) (Date of access: 15.02.2018).
}

2010-2016 we observe the downward tendency in Gazprom production and in Russia gas production as a whole. At the same time, we observe at Rosneft and Novatek production growth. The Lukoil company reaches a stable level of gas production. Gazprom, Novatek, Rosneft, Lukoil are the most significant Russian energy companies concerning capitalization.

\section{Theory}

We understand sustainable growth as sales growth that are in agreement with the company's financial policy [5]. Starry and McCaughey defined high growth as being above $10.5 \%$ per year, average growth as being between 5 and $10.5 \%$ per year, and low growth as less than $5 \%$ per year [6]. The SGR of any company is determined by the following four factors: (a) profit margin, an increase in the profit margin increase the companies' ability to generate funds internally and thereby increase its sustainable growth, (b) net asset turnover, an increase in the companies 'net assets turnover increases the sales generated for each rand in assets, (c) financial policy, an increase in the Debt / Equity ratio increase the firm 's financial leverage (d) dividend policy, a decrease in the percentage of net profit after tax paid out as dividends increase the retention ratio, in turn increasing internally generated equity and thus increasing sustainable growth $[6,7]$. 
The relationship between fixed assets investments and economic growth have become an important issue on today's academia [8]. Achieving existing assets updates and technical progress by fixing asset investment plays a vital role to further adjust the economic structure, enhance the economic strength and speed up economic development.

Most economists would agree that governance is one of the critical factors determining the growth prospects of countries [9]. Influence Corporate Governance factors on SGR is essential and significant [10]. However, also it is another point of view that corporate governance factors have not such a powerful significance on SGR level as financial or environmental factors [4].

Nowadays, companies start to analyze transversal links between social needs, ecology and financial results [11]. The influence of social factors on SGR is proved in the works of many researchers, for example [12].

The influence of Energy factors on SGR was considered in the research of Makridou, Andriosopoulos, Doumpos, \& Zopounidis [13] and others. Hall, Balogh, \& Murphy [14] believe that Energy Return on Investment (EROI) analysis offers a possibility to look into the future in ways that markets seem unable to do if calculated minimum EROI level for Sustainability society.

Through the quantitative analysis of the economic and ecological indicators (Gross Domestic Product per capita, respective, Environmental Performance Index) in correlation with the social indicator (Global Competitive Index), we conclude that the implementation of green strategies by companies leads to sustainable economic growth [16].

Financial strategy is the behaviour of how people and companies evaluate their investments and raise capital for finance company's operations [17]. The most comprehensive financial strategy definition in Russia belongs to Russian scientist I.A. Blank [18]. According to I.A. Blank, financial strategy providing all main "growth" directions such as financial activities, setting long-term financial goals, choice of the most effective ways of goals' achievement, and use financial resources in case of environmental conditions changing". In the same way, Russian scientists T.V. Geniberg, N.A. Ivanova, O.V. Polyakova appointed that "Financial strategy is the plan with the purpose of effective "growth" within the company's mission. Long-term financial goals ensure Company's corporate and business strategy, representing financing by formation, coordination, distribution, and using financial resources without any risk [1921]. High risk is associated with explosive growth and loss of liquidity and profitability in pursuit of market share [18]. Therefore, the purpose of the financial strategy is to increase the company' market value, improvement of the owner (shareholder) welfare and satisfaction of stakeholders interests [22]. Besides, an increase in the cost of business can reflect at the level of assets or liabilities [19]. Under financial growth, we understand an increase in revenue, total assets, profit, equity, etc. Nowadays, especially in the conditions of globalization and in "economic sanction" in Russia, Russian companies must pay to financially sustainable growth more attention. Russian companies' long-term strategy must imply an increase in business activity and growth. The planning and support of future growth is the most crucial goal, which leads to company's value and the welfare of its owners, while unbalanced growth leads to the depletion of company resources and the risk of increasing the debt burden. It is imperative to plan for the future pace of revenue growth because real growth must be combined with the financial capabilities of the company. Too fast growth without sufficient financial sources can lead to the destruction of business value, while too slow growth can transform a company into a target for raiders [22]. Kroeger, Traem, \& Rockenhaeuser (AT Kerney) [23] suggested that companies need to achieve strategic balance regarding growth.

In order to realize a Financial Sustainability Indicators System (FSIS), it is necessary to suggest organizational, market, operational and financial sustainability indicators. FSIS includes the following models: quality of products/ services; management quality; the financial condition indicators (asset quality, resource potential, profit, and profitability); operating indicators (economic) risks. The FSIS' core block is a system of financial condition indicators. Financial condition is also an instrument for sustainable development of other business spheres - social and environmental. In this system, two components product/ service quality and management quality are universal. Other operational risk factors, which take into account specific features of business, are considered in the block of indicators named "Operational risk" (can be called - social risks). Among operating risks, we considered the following types of risks: personal risk, reputation risks, transportation risks, ecological and environmental risks, political risks. Factors of managerial risks are included in a system of indicators named "Management quality" [24]. The financial strategy of Russian Gas Companies lacks sustainability indexes. Moreover, this strategy does not include all indexes influencing the sustainable financial 
growth. Russian gas companies have Energy savings and Energy Efficiency or Environmental programme but have no some energy efficiency, social or environmental coefficients set as the main KPI of the company. So, at the Annual or Sustainability reports, we cannot see such Indexes like EROI, ROEnv, Environmental Rating and at the companies policies not define the main indicators influenced on FSIS. As we can see, Russian gas companies' KPI includes a set of some financial coefficients, which influence the increasing Company's value, but not Financial Sustainability.

\section{Data and Methodology}

\subsection{Population and Sample}

The study covers ten years' period between 2005 and 2016. Data were collected from the annual reports of the four biggest Russian gas companies (Gazprom, Novatek) and oil companies that are also operating in Russian gas market (Rosneft, Lukoil), which 2016 market share is $88,6 \%$ of the total Russia Gas market.

\subsection{Research Hypothesis}

The primary goal is to examine the financial strategy of four biggest Russian gas companies concerning their sustainable growth.
Hypothesis 1. Russian gas companies operate in the same country market and have a common financial growth strategy.

Hypothesis 2. Sustainability Growth Rate provides similar results and has a positive relationship with Russian gas market companies' coefficients supposed for the system of financial sustainability indicators (FSIS): Return on Fixed Assets (ROFA), Current Ratio (CR), Net Profit Growth (NPG), Debt-Equity ratio (DER), Weight Average Cost of Capital (WACC), Return on Environmental expenses (ROEenv), Energy Return on Investment (EROI), Environmental Ratings $(E R)$, Revenue per Employee Ratio (RER), Return on Social Responsibility expenses (ROEsr), Social Responsibility Dummy $\left(S R_{\text {dummy }}\right)$.

\subsection{Methodology}

\subsubsection{Suggested Set of Financial Sustainability} Index System (FSIS) Coefficients

In this Research, we offer the Financial Sustainability Indicators System (FSIS), which indices and tests, which indicators have a more significant influence on companies' sustainable growth. After analysing a big set of financial and non-financial coefficients, we decided to choose a few coefficients that confided to be more suita-

Table 1

Russian Gas Companies “sustainable financial and non-financial indicators” for testing influence on Company' Sustainable Growth Rate

\begin{tabular}{|c|c|c|c|c|}
\hline \begin{tabular}{|c|} 
System \\
Dynamic Model \\
Sustainable \\
Growth areas \\
\end{tabular} & \begin{tabular}{|c|} 
Financial \\
Sustainability \\
Indicators \\
System (FSIS)
\end{tabular} & KPI & Proxy & Calculation method \\
\hline \multirow{6}{*}{ Economy } & \multirow{6}{*}{$\begin{array}{l}\text { Financial } \\
\text { factors }\end{array}$} & Sustainable Growth Rate & $S G R$ & $R M \times A T \times F L \times R$ \\
\hline & & Return on Fixed Assets & ROFA & EBIT/Fixed Assets \\
\hline & & \begin{tabular}{|l|} 
Current Ratio \\
\end{tabular} & $C R$ & Current assets/current liabilities \\
\hline & & Net profit growth & $N P G$ & $\begin{array}{l}\text { An increase of a company s net profit when } \\
\text { compared to a previous quarter s net profit } \\
\text { performance }\end{array}$ \\
\hline & & \begin{tabular}{|l|} 
Debt equity ratio \\
\end{tabular} & DER & Total liabilities/Equity \\
\hline & & $\begin{array}{l}\text { Weighted Average Cost Of } \\
\text { Capital }\end{array}$ & WACC & $\mathrm{WACC}=r_{E} \times k_{E}+r_{D} \times k_{D} \times(1-T)$ \\
\hline \multirow[b]{3}{*}{ Environmental } & \multirow[b]{3}{*}{$\begin{array}{l}\text { Operational } \\
\text { risks }\end{array}$} & $\begin{array}{l}\text { Return on Environmental } \\
\text { expenses }\end{array}$ & ROEenv & $\begin{array}{l}\text { Total Revenue/ Environmental protection } \\
\text { expenses }\end{array}$ \\
\hline & & EROI & EROI & Energy Return on Investments \\
\hline & & Environmental ratings & $E R$ & $\begin{array}{l}\text { Official Gazprom's environmental ratings } \\
\text { on the base of ROEnv = costs concerning } \\
\text { environmental protection and decision of } \\
\text { pollution question/production }\end{array}$ \\
\hline \multirow{3}{*}{ Social } & \multirow{3}{*}{$\begin{array}{l}\text { Social } \\
\text { Responsibility }\end{array}$} & Revenue per employee ratio & $R E R$ & Total Revenue/Total Number of Employees. \\
\hline & & \begin{tabular}{|l|} 
Return on Social \\
Responsibility Expenses \\
\end{tabular} & ROEsr & Total Revenue/Total Social Expenses \\
\hline & & $\begin{array}{l}\text { Social Responsibility } \\
\text { Dummy }\end{array}$ & $S r_{d u m m y}$ & $\begin{array}{l}\text { Social Responsibility variable chose to reflect } \\
\text { the change in the total number of social } \\
\text { responsibility projects for the one year period }\end{array}$ \\
\hline
\end{tabular}


ble for testing. In our opinion, these indicators can be included to Russian gas companies' Financial Sustainability Index System because of having considerable influence on Sustainable Growth Rate (SGR) (see Table 1).

\subsubsection{Financial Strategy Growth evaluation}

We consider Geniberg's methodology as the most comprehensive method for Russian gas companies Financial Sustainable Growth Strategy analysis [19]. The main aspect of the theory of Ivanova, Genberg and Polyakova is the accent on a distinction between financial policy and funding [25] using the interrelation scheme of Assets' profitability, products' profitability and "Du Pont" model. Russian scientists developed $Z$-matrix for the financial strategy growth formation based on the BCG SGR. $Z$-matrix consists of four parts and is based on the assessment of the revenue growth rate and financing growth rate (Fig. 3). Matrix is divided into four squares by average $S G R$ growth and $G$ (revenue growth). Average tempo is calculated on the geometric average tempo:

$$
1+r_{g m}=\sqrt[n]{\stackrel{n}{i=1}^{n}\left(1+r_{i}\right)}
$$

where $r_{g m}$ - average geometric growth, $r$ - growth rate per year, $n-$ a number of years.

Results can show us the following:

I. Strategy Quadrant. Growth, leading to increased business value. In this case, the Company has an excessive capital. The typical financial strategy is growth through internal funding sources. The company's level of retained earnings grows more rapidly than the Equity Growth Rate. In this case, Company sources can increase sales growth and assets through internal funding, but at the same time there may be a risk. For example, a rise in sales can lead to gross profit increase, but according to financial policy, this growth will require increase in assets for increasing production volume. Typically the company has to increase inventory, receivables, and other assets.

II. Strategy Quadrant. Simple growth. The company focused on an aggressive sales policy, as there is a high rate of revenue growth and low financial policy. The company is profitable because of increasing assets. The company may finance various investment projects. If none of the investment options is acceptable, the company doesn't need an additional funding. The Company can use all profit for dividends.

III. Strategy Quadrant. Catch-up growth. Deficient performance. Typical reinvention strategy and or withdrawal from the market (or market segment). For improving their positions in the market, to invest for recovering lost position, in

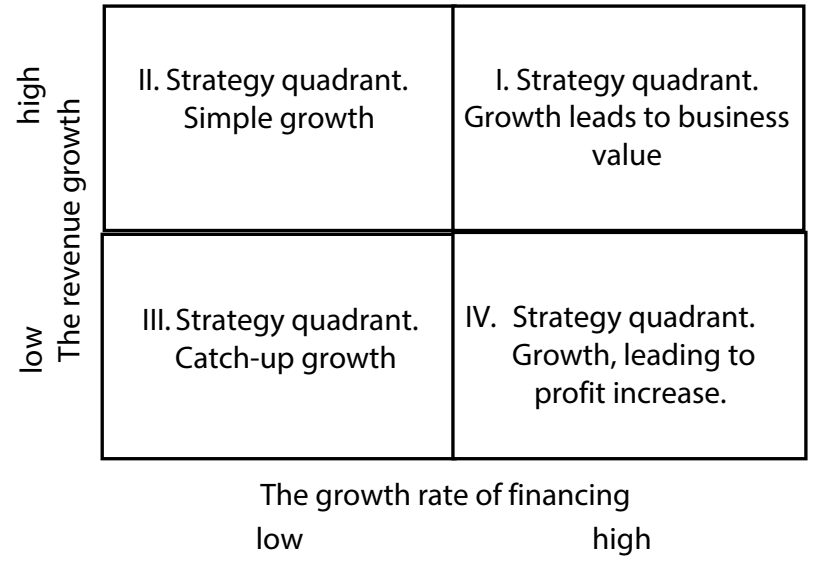

Fig 3. Z-matrix Financial Sustainable Growth Model

reducing the level of investments, the companies may require reinvention and leave the market (or market segment), but cannot achieve significant competitive advantages.

IV. Strategy Quadrant. Growth is leading to increased profits. The strategy is aimed at attracting funds from outside, either through various kinds of loans, either by increasing share capital (issue stocks or bonds). Besides, the bond issue is the highest priority, as it promotes credit rating formation.

To build the matrix the following steps are needed:

1) To evaluate Revenue Growth Rate. This is the calculation of the index AT and PM. The product of these indicators reflects the Sustainable Growth Rate (Revenue). Results of calculation delay value on the vertical axis of $Z$-matrix.

2) For evaluating Financing Growth Rate, we need to calculate the FL and R indicators. The product of these indices reflects Company' Financing Growth Rate (Profit). Calculation results delay value on the horizontal axis of the matrix.

3) Industry average values plotted on the axes of the matrix are set according to the Federal state statistics service.

4) Determined Quadrant 1-4. The company needs to work with an appropriate financial strategy and develop more specific recommendations for the Company's financial management.

This approach allows us to estimate the value of the business terms using growth in revenue and funding. On the basis of $Z$-matrix results, the company must invest in those areas that are most competitive. This analysis is an effective mechanism for the consideration of opportunities for further investment expansion or reduction. $Z$-matrix results can help a company's leaders evaluate their business to compare the attractiveness of different areas of financial activities and to determine the direction of cash flow. 


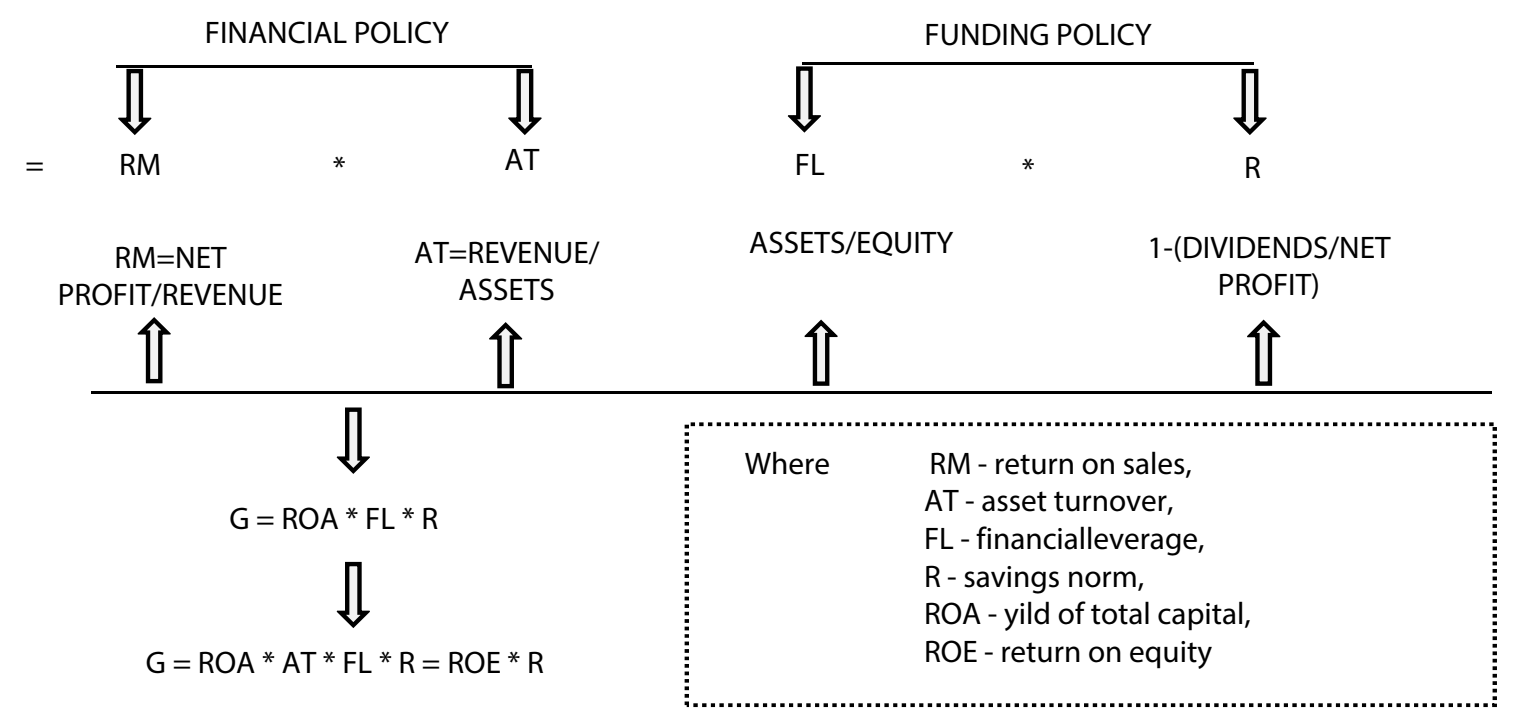

Fig. 4. Sustainable Growth model

\subsubsection{Sustainable Growth Rate Calculation}

For calculation Russian gas companies Sustainable Growth Rate (further-SGR), we choose a sustainable corporate growth evaluation model, developed by Boston Consulting Group. Proposed Sustainable Growth Model schematically represented in the Figure 4. The SGR formula describes the relationship between the return on sales, asset turnover, financial leverage, savings norm, and the sustainable growth rate [25].

Sustainable Growth Rate (SGR) Formula:

$$
S D R=R M \times A T \times F L \times R
$$

where $R M$ - Return on Sales, $A T$ - Asset Turnover, $F L$ - Financial Leverage, $R$ - Savings norm.

\subsubsection{For Hypothesis calculations}

We test number of Variables.

Fundamental variables. As the essential independent variables we introduced in the analysis the company's growth indicators. To identify company's sustainable financial growth characteristics, we used financial and non-financial variables as dependent variables.

Financial factor variables:

Return on Fixed Assets (ROFA), Current Ratio $(C R)$, Net Profit Growth (NPG), Debt Equity ratio $(D E R)$, Weight Average Cost of Capital (WACC).

Environmental factors variables: Return on Environmental expenses (ROEenv), Energy Return on Investment (EROI), Environmental Ratings (ER).

Social factors variables: Revenue per Employee Ratio (RER), Return on Social Responsibility expenses (ROEsr), Social Responsibility Dummy (SRdummy).

Non-fundamental variables:

Social Responsibility variable chose as to reflect the change in the total number of social responsibility projects for the 1 -year period:

$$
\text { CGdummy }=\left\{\begin{array}{l}
1, \text { if }(a), \\
0, \text { if }(b),
\end{array}\right.
$$

where $a$ is project's number increase, $b$ - other.

To test this hypothesis with Dummy variables we used the following regression model:

$$
Y_{i}=a_{1}+a_{2} D_{2 i}+a_{3} D_{3 i}+\beta X_{i}+u_{i}
$$

To test hypothesis 2 we construct regression model:

$$
\ln y=b_{1} \ln x_{1}+b_{2} \ln x_{2}+b_{3} \ln x_{3}+c,
$$

where $Y-S G R, \ln$ - natural logarithm, $b_{1}, b_{2}, b_{3}$ - coefficients, $x_{1}, x_{2}, x_{3}$ - dependence variable (ROFA, CR, NPG, DER, WACC, ROEenv, EROI, ER, $R E R, R O E s r$, SRdummy), c - Dummy variable.

The basic regression model is the Russian scientist Irina Ivashkovskaya model [21]. For this Research Model was modified.

$$
\begin{gathered}
S G R=a R O F A+b C R+c N P G+d D E R+ \\
+e W A C C+f R E R+g R O E s r+ \\
+e R O E e n v+i E R O I+j E R+k_{\text {Dummy }}^{S R}
\end{gathered}
$$

where $S G R$ - Sustainable Growth Rate, ROFA Return on Fixed assets, $C R$ - Current ratio, $N P G-$ Net profit growth, $D E R$ - Debt Equity Ratio, WACC - Average cost of capital, RER - Revenue per employee ratio, ROEsr - Return on social responsibility expenses, ROEenv - Return on environmental protection expenses, SRdummy - Social Responsibility Dummy.

\section{Results}

\subsection{Hypothesis 1 results}

We built Financial Strategy Sustainable Growth $Z$-matrix to analyse Russian gas companies' strat- 
egy based on the sustainable growth concept (see Figure 5, Table 2). $Z$-matrix consisted of 4 parts and based on the assessment of the Revenue growth rate and financial growth rate (profit factors). We mentioned that Russian gas companies' actual revenue growth is higher than $S G R$ growth. In other words, companies ignored financial limitations and took high risks.

The results of Russian gas companies' movement through Z-matrix analysis confirmed Ivashkovskaya's research findings [4] that achieving of Sustainable Growth are not only associated with Profit Growth.

The Figure 5 and the Table 2 show that from 2005 to 2013 Gazprom predominantly was founded in the $Q 1$. This situation shows that the company growth leads to high business value. Gazprom has an oversupply of capital volume. Financial strategy for Gazprom, in this case, is growth through internal financing sources. The company's level of retained earnings growth more rapidly than the equity growth rate. Moreover, Gazprom through internal funding can increase the sales and assets growth. However, at the same time, there may be a risk. Arise in sales could lead to a profit increase, but this growth also requires increases in assets for increasing production volume. Thus, for sustainable growth, Gazprom can increase assets, because additional sales require more labour tools and objects.
If companies are not able to increase their growth, probably, it is because they do not have a corporeal base for this (required production capacities, financial resources or qualified labour resources). Increase in assets is accompanied by the growth of funding sources (either their own ( $R$ indicator in the SGR calculation or by borrowing).

We can see that Gazprom in 2014-2015 transfer to Q3, that characterized deficient performance. However, from 2016, Gazprom again tries to move to $Q 1$ quadrant.

The Figure 5 and the Table 2 show that Novatek mostly was founded in the Q4. However, from 2014 Novatek also transfers to $Q 1$ quadrant.Lukoil from 2005 untill 2011 was in Q1, but from 2011 transfers to Q3 with deficient performance. In 2015, $r$ it was in $Q 2$ and "simple growth" strategy, but from 2016 Novatek returned to $Q 1$. Thus, financial growth strategy prescriptions for Novatek and Lukoil are the same with Gazprom. For many years Rosneft has been in Q3, however, from 2016 Gazprom moved to another Financial Strategy point. Rosneft stays in Q2 "Simple growth". Rosneft is focused on aggressive sales policy with a high rate of revenue growth but deficient financial policy rate. Rosneft funds various strategic investment projects. If none of the investment options is acceptable, the company doesn't need additional funding. a

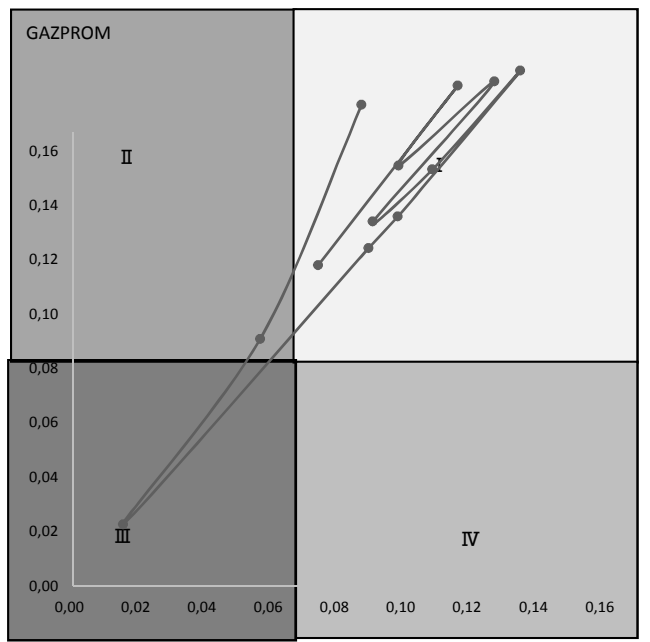

c

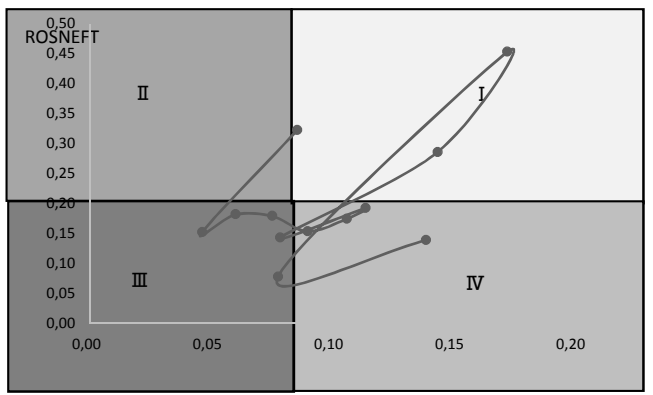

b
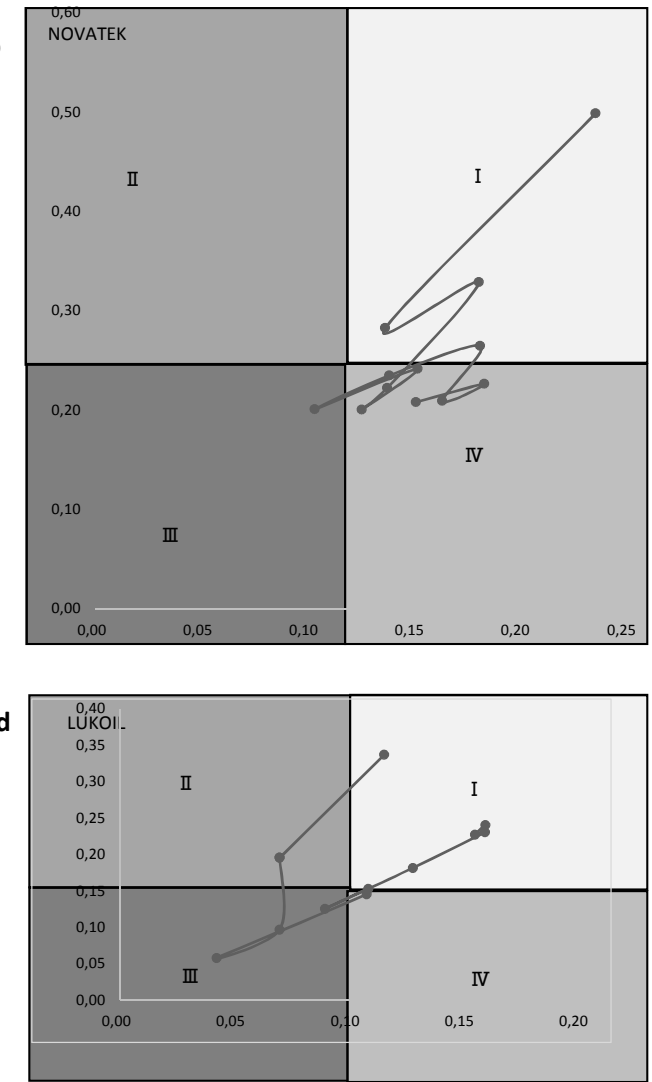

Fig. 5. Company's Z-matrix trajectory results, 2005-2016 (a) Gazprom, (b) Novatek, (c) Rosneft, (d) Lukoil 
Z-matrix results, 2005-2016

\begin{tabular}{|c|c|c|c|c|c|c|c|c|}
\hline \multirow{2}{*}{ Period } & \multicolumn{5}{|c|}{ Replace from Q1 } & \multicolumn{4}{c|}{ Replace from Q2 } \\
\cline { 2 - 9 } & in Q1 & in Q2 & in Q3 & in Q4 & in Q1 & in Q2 & in Q3 & in Q4 \\
\hline $2005-2006$ & SINO, CNPC, CNOOC & - & - & - & - & - & - & - \\
\hline $2006-2007$ & SINO, CNPC, CNOOC & - & - & - & - & - & - & - \\
\hline $2007-2008$ & CNOOC & - & SINO, CNPC & - & - & - & - & - \\
\hline $2008-2009$ & - & CNOOC & - & - & - & - & - & - \\
\hline $2009-2010$ & SINO & - & - & - & CNOOC & - & - & - \\
\hline $2010-2011$ & SINO, CNOOC & - & - & - & - & - & - & - \\
\hline $2011-2012$ & SINO, CNOOC & - & - & - & - & - & - & - \\
\hline $2012-2013$ & SINO & CNOOC & - & - & - & - & - & - \\
\hline $2013-2014$ & - & - & SINO & - & - & CNOOC & - & - \\
\hline $2014-2015$ & - & - & - & - & - & - & CNOOC & - \\
\hline $2015-2016$ & - & - & - & - & - & - & - & - \\
\hline \multirow{2}{*}{ Period } & Replace from Q3 & & & & Replace from Q4 & & \\
\cline { 2 - 9 } & in Q1 & in Q2 & in Q3 & in Q4 & in Q1 & in Q2 & in Q3 & in Q4 \\
\hline $2005-2006$ & - & - & - & - & - & - & - & - \\
\hline $2006-2007$ & - & - & - & - & - & - & - & - \\
\hline $2007-2008$ & - & - & - & - & - & - & - & - \\
\hline $2008-2009$ & SINO & - & CNPC & - & - & - & - & - \\
\hline $2009-2010$ & - & - & CNPC & - & - & - & - & - \\
\hline $2010-2011$ & - & - & CNPC & - & - & - & - & - \\
\hline $2011-2012$ & - & - & CNPC & - & - & - & - & - \\
\hline $2012-2013$ & - & - & CNPC & - & - & - & - & - \\
\hline $2013-2014$ & - & - & CNPC & - & - & - & - & - \\
\hline $2014-2015$ & - & - & SINO, CNPC & - & - & - & - & - \\
\hline $2015-2016$ & - & - & SINO, CNPC, & - & - & - & - & - \\
\hline
\end{tabular}

The analysis of the $Z$-matrix shows that companies' financial strategies are changing from period to period and in some periods have strong fluctuations within one company in the whole sample. However, the most of companies have passed from the $Q 1$ to $Q 2$ or $Q 3$, from $Q 2$ to $Q 3$. Financial strategy evaluation results show that Russian gas companies are financially attractive and have significant results. However, on the one hand, in their annual financial reports companies say about conservative policies and sustainable growth in the coming years, on the other hand, companies' financial performance suggests another situation because of insufficient level of financial indices. This situation reflects the inconsistency of the existing sustainable growth approaches. Russian gas market companies must improve financial strategies according to sustainable growth. It is essential to implement financial sustainable index system in financial reporting with including KPI that can influence on the companies' sustainable growth.

\subsection{Hypothesis 2 results}

Unbalanced financial growth leads to resource deterioration and debt burden risks. That is why it is important to know which indicators (financial and non-financial) concerning Sustainability has a greater influence on the Company's Sustainable Growth as a whole. We calculated a set of financial indicators which allowed us to determine the sustainable growth rate for four Russia largest gas market companies' for the period from 2005 to 2016 (see Figure 6 a-d). Financial leverage and norm of accumulation has a great impact on the companies' SGR. Financial leverage (further $-F L$ ) can influence on the Company's Profit level, changing a ratio of own and borrowed funds (the norm for $F L$ is 1 ). The most aggressive financial policy from the Russian gas companies lead by Rosneft, so Company's Financial leverage is 3,34 and, respectively, the softest policy of financing is conducted by Gazprom since the Financial leverage makes 1,66 . These values show that the share of the loan capital in a balance sheet for Rosneft makes more than $70 \%$, and for Gazprom - no more than $60 \%$. These are rather high rates of characterizing companies' financial dependence and a high level of financial risk. Gazprom shows a low value of a Loan capital share in the total value of Assets because of the relation of Assets to equity 


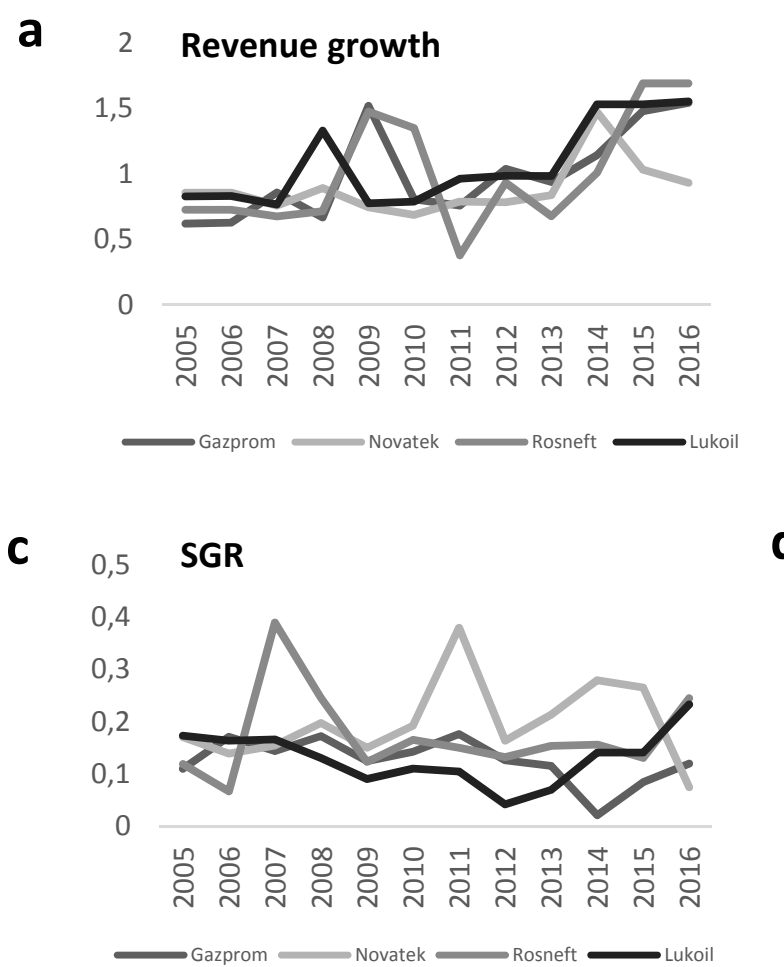

b

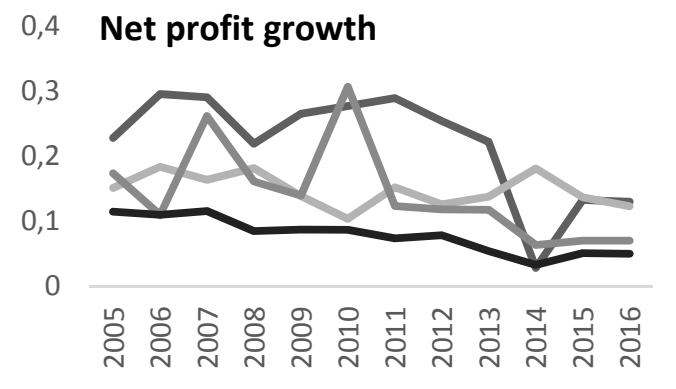

$\longrightarrow$ Gazprom $\longrightarrow$ Novatek Lukoil

d

2 STRATEGIC SPREAD

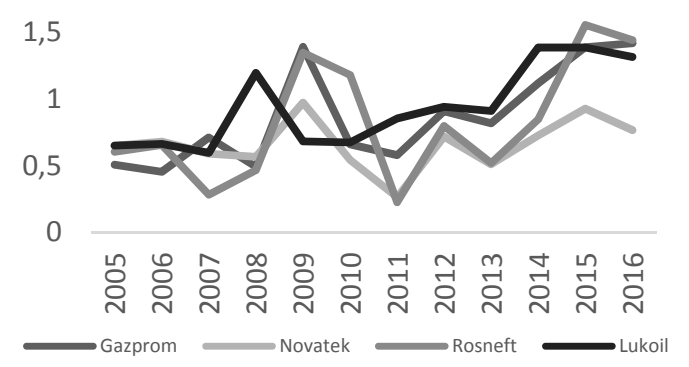

Fig. 6. (a). Revenue growth (b) Net profit growth, (c) SGR growth, (d) Strategic Spread (Revenue Growth-SGR)

less than two. For Novatek, Lukoil, Rosneft this indicator exceeds two marks. Therefore, the share of the loan capital in the Balance sheet of these companies exceeds $50 \%$. Thus, SGR for the period from 2005 to 2016 for theese four companies accepted various values. The lowest level of SGR 0.14 can be observed for Gazprom. However, from the previous periods, SGR of Russian gas companies has increased. Gazprom's $S G R$ increases from 0.12 in 2005 to 0.14 in 2016. Novatek's $S G R$ rapidly increases from 0.09 in 2005 to 0,31 in 2016. Rosneft's $S G R$ increases from 0.13 in 2005 to 0.28 in 2016. Lukoil's $S G R$ further increases from 0.23 in 2005 to 0.31 at the end of 2016. After comparison Russian gas market companies' Revenue Ratio growth, Financial leverage and Sustainable Growth Ratio, we can regard Financial growth strategies issue. Despite the revenue growth, net profitability may be quite low. As we see, Sustainable Growth Rate increases not the same way as Revenue Rate and Net Profit Margin. It was mentioned that Russian gas companies' actual growth of revenue is higher than $S G R$. In other words, companies ignored financial limitations and took high risks.

In recent years, SGR Dynamics was stabilized and nowadays we do not see sharp increasing jumps in $S G R$ level, but observe a strong direction to settle. However, lately the $S G R$ level is less than in previous years that demonstrate the discrepancy between the stated strategies to the actual situation (Fig.6). We evaluated the regres- sions by using pooled regression models with deterministic effects and random effects. We tested influence of ROFA, CR, NPG, DER, WACC, ROEenv, $R D S, E R O I, E R, R E R, R O E s r$, SRdummy on SGR. The result of panel aggression analysis shows that $S G R$ provides similar results and have a positive relationship with Russian gas market companies' coefficients supposed for the system of financial sustainability indicators (FSIS): ROFA, NPG, DER, ROEsr, ER (see Table 3).

Financial Sustainable Growth has been identified as a Growth of strategic and financial results of the company with some key determinants. Net Profit Growth has a positive effect on the growth of Russian gas market companies. According to regression model results $C R$, WACC, ROEenv, RER and SRDummy has a meagre efficiency. EROI demonstrates little relationship with $S D R$, but $E R O I$ is positive in the regression with Return on Environmental expenses and Environmental Ratings. ROEenv is positive in the regression with ROFA, CR. It is excellent findings that Environmental ratings influence on $S G R$ Russian gas market companies. It is recommended to include to FSIS as KPI next coefficients: $S G R$, ROFA, NPG, DER, ROEsr, ER.

\section{Conclusion}

The relationship between Sustainable Growth and Russian gas companies' Financial Strategy was confirmed. We gave recommendations about 
Table 3

\begin{tabular}{|c|c|}
\hline & -1 \\
\hline VARIABLES & $s g r$ \\
\hline \multirow{2}{*}{ rofa } & $0.194^{* *}$ \\
\hline & $(0.0794)$ \\
\hline \multirow{2}{*}{$c r$} & 0.00438 \\
\hline & $(0.0179)$ \\
\hline \multirow{2}{*}{$n p g$} & $0.0138^{*}$ \\
\hline & $(0.00656)$ \\
\hline \multirow{2}{*}{ der } & $0.0682^{* * *}$ \\
\hline & $(0.0237)$ \\
\hline \multirow{2}{*}{ roesr } & $0.0523^{*}$ \\
\hline & $(0.0238)$ \\
\hline \multirow{2}{*}{ wacc } & 0.00298 \\
\hline & $(0.00403)$ \\
\hline \multirow{2}{*}{ roeenv } & 0.00386 \\
\hline & $(0.0203)$ \\
\hline \multirow{2}{*}{ rer } & 0.00238 \\
\hline & $(0.00271)$ \\
\hline \multirow{2}{*}{ eroi } & -0.000130 \\
\hline & $(0.000405)$ \\
\hline \multirow{2}{*}{ er } & $0.0700^{* *}$ \\
\hline & $(0.0345)$ \\
\hline \multirow{2}{*}{ srdummy } & 0.00813 \\
\hline & $(0.0150)$ \\
\hline \multirow{2}{*}{ Constant } & $0.0971^{*}$ \\
\hline & $(0.0584)$ \\
\hline Observations & 48 \\
\hline Number of id & 4 \\
\hline
\end{tabular}

Standard errors in parentheses ${ }^{* * *} p<0.01,{ }^{* *} \mathrm{p}<0.05,{ }^{*} \mathrm{p}<0.1$.

the formation of capital structure and financial strategy concerning companies' sustainable growth. We have chosen and improved Financial Sustainability Indicators System (FSIS). We analysed Russian gas companies' financial growth strategy through Geniberg $Z$ - matrix as well as enhanced Financial Sustainability Indicators
System indexes by identifying, which indicators have a greater influence on Sustainable Growth Rate. Return on fixed assets ratio, net profit growth ratio, Debt equity ratio and Return on social responsibilities cost influence on Russian gas companies' sustainable growth rate and are recommended for FSIS calculation. Great finding is that Environmental Ratings influence Sustainable growth rate. Evaluation results show that companies are financially attractive and have stable results, but could improve Financial Strategies according to Sustainable Growth point of view.

It is the controversial question which factors has more influence on $S G R$ because in other circumstances the results can be different. However, it is interesting to find a way to implement indices influencing on sustainable growth as companies KPI. It is emphasizing that the analysis of the sustainable growth dynamics does not fully reflect financial capabilities of the companies, the level of their revenue and profit growth rate does not fully characterize $S G R$. For that reason this research takes into account non-financial indicators as a possible direction for further development of sustainable growth theory. Since the concept of sustainable development is associated with environmental protection, energy savings, and social factors, we added non-financial factors to the sustainable growth model for checking the influence of "nature" factors on financials. As a result of the analysis, we confirmed the dependence of environmental ratings and returned on social responsibility expenses. Russian gas market companies could pay more attention to the energy, social, environmental and economic determinants that will contribute to sustainable companies' growth. Further, we intend to develop this research testing the dependence of non-financial factors on the companies' financial sustainability as a whole.

\section{Acknowledgments}

We want to express our gratitude to the scientist of the All-Russia Petroleum Research Exploration Institute Prof. Natalia Iskritskaya.

\section{References}

1. Yasuda, T (2005). Firm Growth, Size, Age and Behavior in Japanese Manufacturing. Small Business Economics Journal, $24,1-15$.

2. Esteves, L. A. (2007). A note on Gibrat's law, Gibrat's legacy and firm growth: Evidence from Brazilian companies. Economics Bulletin, 12(19), 1-7.

3. Gupta, P., Guha, S., \& Krishnaswami, S. (2013). Firm growth and its determinants. Journal of Innovation and Entrepreneurship, 2(1), 15. https://doi.org/10.1186/2192-5372-2-15.

4. Ivashkovskaya I, Zhivotova E. (2009). Indeks ustoichivosti rosta: empiricheskaia aprobatsiia na dannykh rossiiskikh kompanii. [Sustainable Growth Index: Empirical Tests for the Russian Companies]. Vestnik of Saint Petersburg University, 8(4), 3-29 (In Russ.)

5. Higgins, R. (1977). How much growth can a firm afford? Financial Management, 6(3), 7-16. https://doi. org/10.2307/3665251. 
6. Rădăşanu, A. C. (2015). Cash-Flow Sustainable Growth Rate Models. Journal of Public Administration, (7), 62-70. [Electronic source] Retrieved from http://www.jopafl.com/uploads/issue7/CASHFLOW_SUSTAINABLE_GROWTH_ RATE_MODELS.pdf (Date of access: 15.02.2018).

7. Ramezani C., Soenen L., Jung A. (2002). Growth, Corporate Profitability, and Value Creation. Financial Analysts Journal, 58(6), 56-67.

8. Li, Z., \& Yang, D. (2015). The Study on the Influence of Fixed Asset Investment and Foreign Trade to the Economic Growth of Ningbo---Based on VAR Model, International Conference on Education Technology, Management and Humanities Science (ETMHS 2015), 271-275.

9. Khan, M. (2008) 'Governance and Development: The Perspective of Growth-Enhancing Governance.' In: Diversity and Complementarity in Development Aid: East Asian Lessons for African Growth. Tokyo: GRIPS Development Forum/ National Graduate Institute for Policy Studies, 107-152.

10. Singhal A. (2014). Corporate Governance, Cost of Capital and Value Creation: Evidence from Indian Firms. IOSR Journal of Economics and Finance. E-ISSN: 2321-5933, p-ISSN: 2321-5925. 4(6) (July-August, 2014), 36-54.

11. D’Amato, A., Henderson, S., \& Florence, S. (2009). Corporate social responsibility and sustainable business. Noth Carolina, Center for Creative Leadership, Greensboro, 102. https://doi.org/978-1-60491-063-6.

12. Paul M. Romer, 1989. Human Capital And Growth: Theory and Evidence, NBER Working Papers 3173, National Bureau of Economic Research, Inc.

13. Makridou, G., Andriosopoulos, K., Doumpos, M., \& Zopounidis, C. (2016). Measuring the ef fi ciency of energy-intensive industries across European countries, Energy Policy Journal, 88, 573-583, https://doi.org/10.1016/j.enpol.2015.06.042.

14. Hall, C. A. S., Balogh, S., \& Murphy, D. J. R. (2009). What is the Minimum EROI that a Sustainable. Energies, 2, 25-47. https://doi.org/10.3390/en20100025.

15. Naz, S, Javed M. et al. (2000). A Study on Length-Weight Relationships (LWR) and Growth Responses of Major Carps Exposed to Lead $(\mathrm{Pb})$, International Knowledge Sharing platform, 3(19), 72-79. https://www.iiste.org/Journals/index.php/ JBAH/article/view/9785.

16. Radu, M. (2012). Empirical study on the indicators of sustainable performance, Sustainability and organizational change Journal, XIV(32), 451-469.

17. Paminto, A. (2016). The effect of capital structure, firm growth and dividend policy on profitability and firm value, European Journal of Business and Management, 8(33), 123-134.

18. Blank I. (2006). Financial Strategy of the enterprise, Kiev, Nika-Center, 520.

19. Geniberg T., Ivanova N., Polyakova O. (2009). Sushchnost' i metodicheskie osnovy razrabotki finansovoi strategii firmy [Nature and Methodological base of the company's financial strategy], Nauchnye zapiski NGUEU [Bulletin of Novosibirsk State University of Economics and Management], 4, 68-88 (In Russ.)

20. Ivashkovaksya I., Pirogov N. (2008). Finansovyi analiz rosta rossiiskikh kompanii [Financial Analysis of Russian Corporate Growth], Audit and Financial Analysis, 6, 0-7. (In Russ.)

21. Ivashkovskaya. (2014). [Does corporate financial architecture contribute to sustainable corporate growth? The evidence from Russian companies], Journal of Corporate Finance research, 4(32), 11-33.

22. Ryabova E. V. (2011). Analiz finansovoi strategii kompanii na osnove modeli ustoichivogo rosta [Analysis of the financial strategy of companies on the basis of the stable growth model]. Finansovaia analitika: problemy i resheniia [Financial Analytics: Science and Experience], 41(83), 19-26. (in Russ.)

23. Thomsen S., Pedersen T. (2000). Ownership Structure and Economic Performance in The Largest European Companies. Strategic Management Journal, 21(6), 689-705.

24. Gerasimova E. B., Redin D. V. (2015). Analysis and managing companies' financial sustainability in turbulent environment, Mediterranean Journal of Social Sciences, 6(4), 138-143. https://doi.org/10.5901/mjss.2015.v6n4p138.

25. Amouzesh, N. (2011). Sustainable Growth Rate and Firm Performance: Evidence from Iran Stock Exchange. International Journal of Business and Social Science, 2(23), 249-255.

\section{Authors}

Alina Steblyanskaya - PhD student, China University of Petroleum; ORCID: 0000-0002-1995-4651; Researcher ID: D-2506-2018 (1008, 18, B, Fuxue Road, 102249, Beijing, China; e-mail: alinamv@bk.ru).

Zhen Wang - PhD, Professor, China University of Petroleum; ORCID 0000-0003-2676-8862 (1301, 18, B, Fuxue Road, 102249, Beijing, China; e-mail: wangzhen@cup.edu.cn).

Elena Vyacheslavovna Ryabova - PhD in Economics, Associate Professor, Financial Management Department, National Research University Higher School of Economics, Branch in Nizhny Novgorod; ORCID: 0000-0002-7829-7452; Researcher ID: L-6762-2015 (25/12, Bolshaya Pecherskaya St., 603000, Nizhny Novgorod, Russian Federation; e-mail: eryabova@hse.ru).

Svetlana Valerievna Razmanova - Doctor of Economics, Professor, Head of Laboratory, Branch Office of LLC Gazprom VNIIGAZ in Ukhta; Scopus Author ID: 56117404000; ORCID: 0000-0002-3865-8508; Researcher ID: B-1442-2014 (1a, Sevastopolskaya St., Ukhta, Republicc of Komi, 169300, Russian Federation; e-mail:s.razmanova@sng.vniigaz.gazprom.ru). 